\title{
ANNOUNCEMENT \\ POLICY ON ILLUSTRATIONS FOR THE JOURNAL
}

Beginning with the January 1988 issue, the Journal of Paleontology will change to a page size of $81 / 2 \times 11$ inches. Therefore, effective immediately, figures accompanying manuscripts submitted for publication must be at full page size of $18.3 \times 23.3 \mathrm{~cm}$, or at double column width of $18.3 \mathrm{~cm}$, or at single column width of $9.0 \mathrm{~cm}$. All figures must be submitted at publication size and each mounted upon $8^{1 / 2} \times 11$ in. $(21.5 \times 28 \mathrm{~cm})$ white cardboard. Only original prints of half-tone illustrations will be accepted, because those that previously have been screened will not provide acceptable reproduction. Use numbers (not letters) to identify multiple parts of a figure. Half-tones mounted as multiple square or rectangular parts of a figure should be butted together along straight lines with numbers affixed on the lower right-hand corners of the different parts.

\section{ANNOUNCEMENT}

\section{NEW MEMBERS OF THE PALEONTOLOGICAL SOCIETY}

In accordance with the By-laws of The Paleontological Society, the names of new members are listed below:

Gil, APril VANCAMP, P.O. Box 2723 C/S, Socorro, NM 87801.

Grene, MARJORIE, 206 Ridgedale Rd., Ithaca, NY 14805.

\section{ANNOUNCEMENT}

\section{COLLECTION TRANSFER}

\author{
EDWARD C. WILSON AND LOUELLA R. SAUL \\ Natural History Museum of Los Angeles County, 900 Exposition Blvd., \\ Los Angeles, California 90007
}

The Natural History Museum of Los Angeles County, Invertebrate Paleontology Section (LACMIP), recently received the collection of invertebrate fossils (except Protozoa) formerly housed in the University of California at Los Angeles, Department of Earth and Space Sciences. This collection was highly rated in the CONARIP Report (Glenister, 1977). It contains approximately one million specimens, including name-bearing types for 307 species.

Two other universities, the California Institute of Technology and the University of Southern California, also transferred important collections of invertebrate fossils to LACMIP in recent years. With these additions, LACMIP now is the only major collection of invertebrate fossils in southern California, with an estimated holding of three million specimens, including name-bearing types for 836 species.

Borrowers should return specimens to LACMIP upon completion of loans.

\section{REFERENCE}

GlenisTeR, B. F. (Chairman). 1977. Fossil invertebrates-collections in North American repositories 1976. A report of the Paleontological Society Ad Hoc Committee on North American Resources in Invertebrate Paleontology (CONARIP). University of Iowa, $67 \mathrm{p}$. 